FOLIA HISTORICA CRACOVIENSIA, 22: 2016, s. 129-140

DOI: http://dx.doi.org/10.15633/fhc. 2075

Krzysztof Gombin

Katolicki Uniwersytet Lubelski Jana PawŁa II

\title{
„Ścisk na podatki, a suknia tak długa, że się po ziemi wlecze", \\ czyli o politycznym aspekcie mody \\ w kazaniach ks. Józef Męcińskiego, \\ wygłoszonych w lubelskim kościele św. Ducha w czasie Sejmu Wielkiego
}

Ksiądz Józef, a właściwie Wojciech - Józef to imię zakonne, Męciński (1748-1814)', „reformat, wsławiony tego zakonu kaznodzieja”, jak scharakteryzował go Kajetan Koźmian ${ }^{2}$, to postać mająca od dawna swe miejsce zarówno w opracowaniach dotyczących dziejów polskiej homiletyki, jak i idei społeczno-gospodarczych czasów stanisławowskich ${ }^{3}$.

W latach 1786-1793 Męciński przebywał w Lublinie, gdzie poczynając od 1788 roku, wygłosił w kościele św. Ducha serię kazań kierowanych do szlachty, w których nawiązywał do aktualnych wydarzeń - obrad Sejmu Czteroletniego. Jego opinie o modzie (a także, choć w mniejszym stopniu, o architekturze i ceremoniale publicznym) można oczywiście rozpatrywać w kontekście tradycji zakonnej, ale także, a w moim przekonaniu przede wszystkim, w kontekście szerszej dyskusji o modzie, obyczaju i roli rzemiosła, jaka miała miejsce w Rzeczypospolitej

Z racji ograniczonego miejsca nie przedstawiam tu szczegółowej biografii Józefa Męcińskiego. O podstawowych faktach z jego życia por. G. A. Wiśniowski, Męciński Wojciech, [w:] Polski stownik biograficzny, t. 20, Wrocław 1975, s. 495-496.

K. Koźmian, Pamiętniki, t. 1, oprac. M. Kaczmarek, F. Pecold, wstęp i komentarz J. Willaume, Wrocław-Warszawa-Kraków 1972, s. 221.

3 A. Jougan, Homilie polskie, Lwów 1902, s. 341-348; A. J. Zakrzewski, Idee Oświecenia w kazaniach polskich. Studium literacko-socjologiczne, Częstochowa 1986, passim; M. Ślusarska, Sejm Czteroletni w okolicznościowym kaznodziejstwie lat 1788-179o, [w:] Ku reformie państwa i odrodzeniu moralnemu człowieka, red. P. Żbikowski, Rzeszów 1992, s. 65-80. 
w czasach stanisławowskich. Wygłoszone w Lublinie kazania ukazały się drukiem, najpierw w wyborze, w postaci broszurek (kazanie o potrzebie krajowego wojska oraz kazanie o dobrowolnej ofierze ${ }^{4}$ ), a potem w całości, jako dwutomowy zbiór ${ }^{5}$. Pomimo iż w kazaniach Męcińskiego można dopatrzeć się pewnych nawiązań do lubelskiej tradycji trybunalskiej (wśród odbiorców byli także deputaci), wiązać je jednak trzeba $z$ innym, bardziej „ogólnokrajowym” nurtem ${ }^{6}$.

Już przed blisko trzydziestu laty Andrzej Jan Zakrzewski przypisał Męcińskiego (i słusznie) do nurtu promującego w kaznodziejstwie idee merkantylistyczne i fizjokratyczne ${ }^{7}$, szczególnie akcentującego rolę pracy jako elementu mogącego przyczynić się do odrodzenia Rzeczypospolitej. Spośród kazań głoszonych podczas Sejmu Czteroletniego w literaturze przedmiotu szczególną uwagę zwracano na kazanie Męcińskiego o dobrowolnej ofierze na wojsko9; ostatnio uczynił to Richard Butterwick, a przed nim Magdalena Ślusarska ${ }^{10}$. Co znamienne, aspektów związanych z szeroko rozumianą sztuką w kazaniach Męcińskiego dotąd nie poruszano.

Najważniejsze z punktu widzenia niniejszych rozważań jest kazanie zatytułowane O chronieniu się troickiego duchownego trądu z drugiego tomu Kazań niedzielnych i świętalnych, a mówiąc dokładniej - jego część dotycząca ubiorów. Interesujący nas fragment rozpoczyna się w sposób następujący:

W trądzie sukni wyraża się zbytek w odzieniu. Bo iako suknia splamiona trądem, niegodnym czyniła ofiarowania, y nieczystym w oczach ludzkich trędowatego; tak przepych y nieskromność w odzieniu potępia zbytkuiące osoby o wykroczenia przeciw prawom wszelakim. Osobliwie te: które się stroią nad urodzenie swoie y nad wą-

${ }_{4}$ Zob. Kazanie o dobrowolney ofierze na naglace potrzeby oyczyzny w dzień Oczyszczenia Nayswiętszey Maryi Panny w kosciele S. Ducha... miane..., Lublin 1789; Kazanie o potrzebie woyska y iego podległości z ewangelij na niedziele III po Trzech Królach, o setniku żołnierzu, miane w kosciele lubelskim Świętego Ducha..., Lublin 179o. Zob. także I. Dziok-Strelnik, Bibliografia starych druków lubelskich 1630-180o, Lublin 1997, s. 305-306.

5 Zob. J. Męciński, Kazania niedzielne y świętalne przez x. Józefa Męcińskiego Prowincyi Mało-Polskiey reformata kaznodzieię zebrane w kościele Lubelskim u S. Ducha Powiedziane i do druku za Dozwoleniem Zwierzchności Podane, t. 1-2, Kraków 1791-1793.

${ }^{6} \mathrm{Z}$ tego też powodu kaznodziejstwo Męcińskiego pominąłem w pracy o Trybunale Koronnym. Zob. K. Gombin, Trybunat Koronny. Ceremoniat i sztuka, Lublin 2013.

7 Zob. A. J. Zakrzewski, Idee Oświecenia..., dz. cyt., s. 56n.

8 Zob. A. J. Zakrzewski, Idee Oświecenia..., dz. cyt., s. 91.

9 Zob. M. Ślusarska, Sejm Czteroletni w okolicznościowym kaznodziejstwie..., dz. cyt., s. 65-8o.

10 Zob. R. Butterwick, Polska rewolucja a Kościół katolicki, tłum. M. Ugniewski, Kraków 2012, s. 329; M. Ślusarska, Sejm Czteroletni w okolicznościowym kaznodziejstwie..., dz. cyt., s. 65n. 
tek swoiey fortuny. Które się stroią nad swoy stan, wiek y czas. Wytkniymy po części tę wieloraką nieprawość. Ludzie powini używać odzienia podług urodzenia, urzędu y dostoyności, iako Monarcha na Tronie, Xiądz przy Ołtarzu, Sędzia na Magistraturze, Nauczyciel w Szkole, Żołnież w Obozie \&c suknia powinna się zgadzać z urzędem, wskazywać czym kto iest [...] Atoli przeklęty przepych ludzki osobliwie kobiet miesza ten chwalebny dystynkcyi w stanach porządek. Zachciewa się tego y na to się przesila, żeby więc Miasta w stroieniu się wyrównywały Dworom, a osoby rzemieślnicze od szynku y kuchni nawet, iednakowo okazywały się iak Urzędniczki Jaśnie Wielmożne. A to iest, daruicie mi że powiem, głupstwo. Ten przepych nie zatrze tey skazy urodzenia twoiego, ale ie śmiesznieyze uczyni [...]. Ludzie powinni nosić się w odzieniu podług wymiaru swoiey fortuny $[\ldots]^{11}$.

Sam pomysł porównania zbytku do niebezpiecznej choroby nie jest oryginalny i spopularyzowany został w opinii publicznej dzięki „Monitorowi”, w którym już w 1777 roku Józef Epifani Minasowicz pisał: „Zbytek to straszna poczwara zarażająca tych wszystkich, którzy się do niego cisną, a ci zarażają potem drugich tak dalece, że ta zaraza po całym rozchodzi się kraju" ${ }^{12}$. Druga idea zawarta w cytowanej powyżej wypowiedzi Męcińskiego znana była opinii publicznej od dawna. Przeciwko kosztownym strojom noszonym zwłaszcza przez mieszczan „komparujących stanowi szlacheckiemu” szlachta występowała w instrukcjach sejmikowych już w czasach saskich ${ }^{13}$. Krytyka stylu życia, w tym także ubioru niezgodnego z przynależnością stanową, obecna była także na łamach „Monitora” ${ }^{14}$. Trzeba przypomnieć, że już w 1774 roku „Monitor” proponował wprowadzenie mundurów wojewódzkich: „za wprowadzeniem takiego zwyczaju ustanowiłaby się oczywista między szlacheckim stanem i inszymi stanami różnica, wściągnienie zbytku w ubiorze w pisane prawa" ${ }^{15}$.

W dalszej części kazania o ubiorach Męciński podkreślał:

${ }^{11}$ J. Męciński, Kazania niedzielne y świętalne..., t. 2, s. 29-30.

${ }_{12}$ Cyt. za: J. Kornacki, Problematyka zbytku w publicystyce „Monitora” (1765-1785), „Kwartalnik Historii Kultury Materialnej” (1985) nr 4, s. 420.

${ }_{13}$ Zob. J. Kornacki, Problematyka zbytku w publicystyce „Monitora”..., dz. cyt., s. 424.

${ }^{14}$ Zob. J. Kornacki, Problematyka zbytku w publicystyce „Monitora”..., dz. cyt.

${ }^{15}$ Cyt za: J. Kornacki, Problematyka zbytku w publicystyce „Monitora”..., dz. cyt., s. 418. Por. T. Jeziorowski, A. Jeziorkowski, Mundury wojewódzkie Rzeczypospolitej Obojga Narodów, Warszawa 1992. Por. też: B. Biedrońska-Słotowa, Polski ubiór narodowy zwany kontuszowym, Kraków 2005, s. 106n; K. Ajewski, O ubiorze sejmowym 1776-1815, [w:] Arma virumque cano. Profesorowi Zdzisławowi Żygulskiemu w osiemdziesięciopięciolecie urodzin, Kraków 2006, s. 399n. Jak pisał Vautrin: „Mundury te ozdobione epoletami łechtały próżność ich posiadaczy, nadawały bowiem nawet służbie domowej wygląd oficerów, ale sejm 178 o zniósł galony i epolety”. H. Vautrin, Obser- 
[...] w zbytku odzienia nie ma się tam względu na swoie dobra, nie miarkuie się na co nas stanie, tylko żeby Chiny, Konstantynopol, wszystkie cudzoziemskie Fabryki stroiów do naszego gustu przyciągnąć, ba gdyby można było do naszey okazałości cały świat kupić. Czyliż bowiem ta wytworność odzienia wystarcza dochodom naszych maiątków, zyskom naszego kunsztu? Skwirczycie na ciężkość teraźniejszych czasów, narzekacie na wielość podatków, ale więcey zwodzicie was samych niż nas. Scisk na podatki, a suknia tak długa, że się po ziemi wlecze! Mówicie, narzekacie, ciężkie czasy. Handel ustaie, w polach nieurodzay, na przedarzy nie masz odbytu, rzemieślnik nie doczeka się roboty zgoła, nie masz w kraiu pieniędzy, ni wiary ni rzetelności. Ale iak temu wierzyć, złe czasy w domach, a obfite w stroiach? Złe czasy, pokażce ie takie w podłości a przynaymniey w przystoyności odzienia, według waszego stanu, y wątku fortuny. Zbytek w odzieniu ten to ten czyni złe czasy: że już dla tego nie płaci się służącym, zaniedbuie się Jałmużny, zapomina się o wychowaniu dzieci \&c: że się trzeba modnie y pięknie pokazać, y nie dać się bogatszym w stroiach przezwyciężyćc ${ }^{16}$.

W powyższym fragmencie mamy zawarte najważniejsze idee gospodarcze wyznawane przez kaznodzieję, a popularne w stanisławowskiej Polsce. Nie sposób wymienić tu wszystkich przykładów. Wskażmy jednak kilka. Zbytkiem zajmowały się konstytucje sejmowe z lat 1776 i 1780. Uważano, że jest on złem - grzechem wynikającym z ludzkiej próżności. Zbytek powoduje odpływ pieniędzy za granicę, a przez to naraża kraj na zubożenie. W „Monitorze” z 1774 roku czytamy:

Zbytek zaś więcej pokrzywdza publiczne dobro przez używanie rzeczy szacownych, które nie rodzą się, ani nie robią w kraju, a przecież psują się. Takie są w Polszcze sukna i płótna cienkie, materie jedwabne, koronki cienkie, galony i tysięczne inne wymysły [...] Potrzeba je zaciągać z zagranicy i drogo przepłacać a przez to ustawicznie otwiera się brama do wyprowadzania złota i srebra nieznacznie z kraju ze szkodą jego dla wzbogacenia cudzoziemców z pokrzywdzeniem obywateli ${ }^{17}$.

Pamiętać należy, że wprowadzone przez sejm w 1776 roku mundury wojewódzkie winny być szyte $z$ sukna krajowego ${ }^{18}$, a dziać się tak miało, jak wyjaśniono

wator w Polsce, [w:] Polska stanisławowska w oczach cudzoziemców, t. 1, wstęp i oprac. W. Zawadzki, tłum. J. I. Kraszewski, Warszawa 1963, s. 777.

16 J. Męciński, Kazania niedzielne y świętalne..., t. 2, dz. cyt., s. 30.

${ }_{17}$ Cyt. za: J. Kornacki, Problematyka zbytku w publicystyce „Monitora”..., dz. cyt., s. 421.

18 Zob. A. Urbaniak, Ubiory szlachty polskiej w czasach stanisławowskich $w$ opinii współczesnych, „Kwartalnik Historii Kultury Materialnej” (1985) nr 3, s. 466. Tu też liczne przykłady przywdziewania „dawnych strojów” podczas Sejmu Wielkiego. 
w konstytucji, po to, aby „[...] zachęcić krajowe manufaktury, a przeto wychodzącym za granicę pieniądzom niejaką uczynić tamę, a stan rycerski i senatorski w przyzwoitej zachować dystynkcji” ${ }^{19}$. W takichże, szytych z rodzimych materiałów mundurach wojewódzkich mieli występować kawalerowie ostatecznie nieutworzonego Orderu św. Izydora ${ }^{20}$, co miało być swoistą manifestacją poglądów ekonomicznych.

Sam Męciński powracał do wspomnianego powyżej wątku jeszcze wielokrotnie $^{21}$. Jego swoistym fizjokratycznym mottem jest zastępujące zdanie:

Ten dom y Kamienicę w których mieszkasz, winieneś pracowitemu Mularzowi, lub Cieśli. Te suknię która nagość twoię odziewa y która cię zdobi, zrobiła ręka krawiecka. To obuwie które cię od zimna i skaleczenia ochrania winieneś przysłudze podciewego Szewca. Ten chleb który iesz na zatrzymanie życia, winieneś mozołowi chłopka rolnika w pocie czoła uprawiaiącego ziemię. [...] Ty niemi wzgardzisz, a oni, Rzemieślnicy, naiemnicy, służący, rolnicy, więcey przynoszą użytku Kraiowi, niż dumne Filozofy roiące dzikie układy, niż Panięta próżnuiące, zniewieściałe zarażaiące świat zgorszeniem y rozpustą ${ }^{22}$.

Notabene widzimy tu też, jaką rolę przewiduje autor dla ubiorów - praktyczną i nic poza tym. W tym miejscu, zapewne właśnie ze względu na swój stan zakonny, idzie dalej niż większość ówczesnej opinii publicznej.

Już w cytowanym wcześniej fragmencie Męciński podkreślał, że kobiety są bardziej podatne na modowy zbytek niż mężczyźni. Wątek ten rozwinięty został w dalszej części kazania:

Że biedny mąż musi ostatni grosz łożyć, zapożyczyć się gdzie można, uiąć swoiey gębie, żeby dogodził grymasom pyszney Jejmości, żeby iey nie obraził, całego piekła nie

19 Cyt. za: T. Jeziorowski, A. Jeziorkowski, Mundury wojewódzkie..., dz. cyt., s. 14.

${ }_{20}$ Zob. Nayskuteczneyszy sposób poprawy powszechney gospodarstwa w nasz kray wprowadzenia uformowanie kraiowey kompanii ekonomiczney który projekt tu się podaie, t. 1, Warszawa 1783.

${ }_{21}^{21}$ „Produkcja krajowa mogłaby wyżywieniu i odzieniu naszych dogodzić, wystarczyć, ale chciwość nasza, kaprys i pycha, po te rzeczy aż poza morza i poza granice szalenie wybiega. Fortuna, majątek mogłyby nas, dom, czeladkę, dostatecznie utrzymać, ale my chcemy ją powiększać z ubożenia cudzego, albo ją trwoniemy na niepotrzebnie potrzebnych”. J. Męciński, Kazania odświętne, t. 1, Kraków 1799, cyt. za: A. J. Zakrzewski, Idee Oświecenia..., dz. cyt., s. 102.

${ }^{22}$ J. Męciński, Kazania niedzielne y świętalne..., t. 2, dz. cyt., s. 386. Por. A. J. Zakrzewski, Idee Oświecenia..., dz. cyt., s. 69. W innym kazaniu Męciński dodaje, że „Ciekawość Filozofów dzisieyszych wymyśliła do latania Balony [...]”. J. Męciński, Kazania niedzielne y świętalne..., t. 1, dz. cyt., s. 437. 
wzruszył [...] Coz za potrzeba? Co za przystoyność, żeby Damy Polskie przeymowały stroie cudzoziemskie Amerykanek, Turkinek \&c: pozwolmy im tego przepychu dogadzaiąc ich kaprysowi; ale im życzmy y namowmy ie do tego, żeby z modą cudzoziemską przyodziały się w cnoty, skromności, wstydu, ostrożności i osobności zwyczayne kobietom tamtych narodów ${ }^{23}$.

Ten motyw był popularny w polskim piśmiennictwie od dawna. O szczególnej miłości kobiet do drogich, a nie zawsze potrzebnych przedmiotów luksusowych pisano np. przy okazji krytyki ceremoniału Trybunału Koronnego. Komentując słowa Męcińskiego, nie sposób nie przywołać Ignacego Krasickiego i jego Żony modnej. Trzeba jednak wskazać na pozytywny wzorzec stworzony przez Księcia Poetów, a mianowicie Panią Podstolinę, która ubierała się tylko w stroje szyte z materiałów krajowych. Problem widzieli zresztą także cudzoziemcy. Hubert Vautrin w relacji o stanisławowskiej Polsce pisał: „Kobiet w stroju cudzoziemskim jest znacznie więcej niż mężczyzn i tak samo jak Francuzki, są one niewolnicami mody. Zaledwie w Paryżu powstaje nowy strój, rodzi się najdrobniejsza zmiana $\mathrm{w}$ przybraniu toalety, musi ona natychmiast trafić z krawieckim manekinem do Warszawy, a stąd na prowincję"24.

Godna podkreślenia jest też myśl Męcińskiego o cnocie egzotycznych kobiet noble savage to topos obecny zarówno w literaturze, jak i sztukach plastycznych czasów oświecenia, a genezą sięgający oczywiście czasów wcześniejszych ${ }^{25}$.

Warto jednak jeszcze raz zaznaczyć, że Męciński w wielu sprawach był bardziej radykalny niż większość szlacheckiej opinii publicznej, do której przemawiał. W omawianych tu kazaniach bardzo zdecydowanie opowiadał się przeciwko przedstawieniom teatralnym, które tradycyjnie były przecież integralną częścią zarówno ceremoniału sejmowego, jak i trybunalskiego ${ }^{26}$. Na ten temat mówił w Lublinie:

${ }_{23}$ J. Męciński, Kazania niedzielne y świętalne..., t. 2, dz. cyt., s. 30-33.

${ }^{24}$ H. Vautrin, Obserwator $w$ Polsce, dz. cyt. Por. A. Roćko, Rola stroju francuskiego w literaturze polskiej drugiej połowy XVIII wieku, [w:] Europejski wiek osiemnasty. Uniwersalizm myśli, różnorodność dróg. Studia i materiały, red. M. Dębowski, A. Grześkowiak-Krwawicz, M. Zwierzykowski, Kraków 2013, s. 164.

${ }_{25}$ Por. np. M. Prejs, Egzotyzm w literaturze staropolskiej. Wybrane problemy, Warszawa 1999, passim; R. Rosenblum, Transformations in late eighteenth century art, Princeton 1967, s. 45n. W 1785 roku Joseph Wright of Derby wystawił obraz przedstawiający indiańską wdowę, jak pisze Rosenblum: „to emphasize the stoicism of this noble savage”.

${ }_{26}$ Zob. J. Lileyko, Zamek Warszawski, rezydencja królewska i siedziba władz Rzeczypospolitej (1569-1763), Warszawa 1984, s. 163n; K. Gombin, Trybunał Koronny..., dz. cyt., passim. 
Dziś nam dziś w tych okropnych czasach nie trzeba Treffnisiów widokami próżności oczy ludzkie łudzących, ale mężnych żołnierzy na obronę Oyczyzny. Dziś nam nie przystojno do komedialni na rozrywki cisnąc się, gdzie potrzeba napełniać świątynie Pańskie, ścieląc się przed Tronem Miłosierdzia za podźwignięcie Oyczyzny. Widoki próżności czas zabieraią najdroższy. Nierząd, truie młodzież, i wygładza Rodzay ludzki po większey części. Bogdayby te koszty łożone na te bezprawia obrocone były na Aukcye Woyska, powinniśmy uczynić Kraiowy najmilszą ofiarę, a zmniejszyć liczbę próżniaków [...] Starzy Polacy Oycowie nasi, kiedy pilnowali Prawa nie kmedyi, i nie płochych rozrywek, umieli siebie wspaniale rządzić, i zaradzić skutecznie dobru Oyczyzny. [...] Mylemy się, gdy rozumiemy, że podobno Teatralne widoki do naprawy złych obyczayow zmierzają, komedya nie naprawi złego, moc Prawa to go sama może ukrócić ${ }^{27}$.

W innym miejscu zaś dodawał: „Nie szli oni [przodkowie] na Woyny od Gotowalni y Teatrow, ale od nabożeństwa" ${ }^{28}$.

Pogląd taki kłócił się także na przykład z interpretacją „Monitora” z 1769 roku:

Mieć w kraju okazałe kościoły, pałace, gmachy, mieszkania i ozdabiać je i siebie i pojazdy swe przystojen, obfitować w dostatki dla swej wygody i uciechy i dla drugich pomocy to nie zbytek, ale gust, ochędóstwo i bogactwa każdemu krajowi pożądane [...]. Złe jest natomiast przebierać w strojach i za modną fraszkę za granicę miliony wysyłać $[\ldots]^{29}$.

Dodać jednak należy, że zdarzało się, iż wznoszenie okazałych budowli publicznych było krytykowane jako zabieg drogi, a więc wymagający nakładania nowych podatków ${ }^{30}$.

Najbardziej radykalnie występował jednak Józef Męciński przeciwko dworskim kaplicom i prywatnym nabożeństwom.

Pyszni nie daią przywieść się do Kościołów na wyrządzenie Czci Bogu uroczystey z wiernemi, bo sobie stawiaią Dworskie Kaplice, y formuią do humoru nabożeństwo prywatne. Bezbożni, bo nie stawaią w obliczu Boga w należytym układzie ciała y du-

${ }^{27}$ J. Męciński, Kazania niedzielne y świętalne..., t. 1, dz. cyt., s. 391-392 (Kazanie na niedzielę vi po światkach o stanie żebraków A.D. 1788).

${ }_{28}$ Kazanie o potrzebie krajowego woyska..., nlb [s. 23].

29 Cyt. za: J. Kornacki, Problematyka zbytku w publicystyce „Monitora”..., dz. cyt., s. 421.

${ }^{30}$ M. Sołtyk, Mowa Jw. JMCI Xiędza [...] Koadiutora Kantora Gnieźnieńskiego Prezydenta Trybunału Koronnego [...] miana w Lublinie przy Limicie Trybunału, Roku 1786, Miesiąca Grudnia, dnia 20, [Lublin]. 
cha [...] Nie mam w prawdzie tyle śmiałości następować na Dworskie Kaplice, na Modlitewnie prywatne; bo wiem, że tey łaski Kościół niektórym pozwala [...] Atoli niech mi będzie wolno zapytać się, czy te nabożeństwa prywatne, pokoiowe i dworskie, nie dzieią się z krzywdą Kościołów y nie ubliżaią uroczystey czci Bogu w Kościołach? Jakże nie, kiedy częstokroć w domu, w Pokoiu, w Kaplicy Dworskiey chcemy Mszy Świętey słuchać, żebyśmy nie pospolitowali z gminem, żebyśmy nie bywali na naukach, na kazaniach które sądzemy, że są iedynie dla Parafianów y Prostaków, nie dla nas, żebyśmy nie widzieli się z kapłanem którego nienawidzemy, y któremu nie chcemy dziesięciny zapłacić; żeby nas nie uderzały gwałtowne potrzeby Kościoła, które iako Kollatorowie mielibyśmy zastąpić załatwić? [... $]^{31}$.

Reasumując, w kilku zdaniach lubelskiego kazania Józefa Męcińskiego mieści się właściwie esencja dyskusji z czasów stanisławowskich dotycząca strojów i zbytku (brak jedynie wątku stroju narodowego), część jego poglądów zdaje się jednak całkowicie oryginalna.

Trudno się dziwić, że Męciński w kazaniach zajął się ubiorem, który w nowożytnej Europie miał niebagatelne znaczenie polityczne ${ }^{32}$, a podczas Sejmu Wielkiego zyskał w Rzeczypospolitej szczególny wymiar. Nie czas tu i miejsce, aby mówić o jego symbolicznym wówczas znaczeniu ${ }^{33}$. Słowa wypowiedziane przez Męcińskiego są ciekawe nie tylko z perspektywy tego, co było, ale i tego, co wkrótce się miało się wydarzyć. Przypomnijmy jedynie na koniec, że ubóstwo stało się swoistą cnotą polityczną, a braki w odzieniu postrzegano niekiedy w spo-

${ }^{31}$ J. Męciński, Kazania niedzielne y świętalne..., t. 1, dz. cyt., s. 456-457. Notabene tego typu poglądy bardziej kojarzyć się mogą z jansenizmem niż katolicyzmem. Panu prof. Piotrowi Krasnemu dziękuję za zwrócenie mi uwagi na ten problem, który zasługuje zresztą na osobne opracowanie.

${ }^{32}$ Por. P. Mansel, Dressed to rule. Royal and court costume from Louis XIV to Elizabeth II, New Haven-London 2005, passim.

${ }^{33} \mathrm{Z}$ licznych prac na ten temat por. np.: A. Urbaniak, Ubiory szlachty polskiej..., dz. cyt., s. 466n; K. Maksimowicz, Konstytucja 3 maja $w$ anonimowej poezji politycznej lat 1791-1792, [w:] „Rok Monarchii Konstytucyjnej”. Piśmiennictwo polskie z lat 1791-1792 wobec Konstytucji 3 maja, red. T. Kostkiewiczowa, Warszawa 1992, s. 86n; J. Dumanowski, Francuski czy niemiecki. Francuska moda, rywalizacja społeczna i elitarna tożsamość w Polsce xvirI wieku, [w:] W strone Francji... Z problemów literatury i kultury polskiego Oświecenia, red. E. Wichrowska, Warszawa 2007, s. 145n; A. Roćko, Kontusz i frak jako symbole postaw osiemnastowiecznych Sarmatów, [w:] $W$ stronę Francji... Z problemów literatury i kultury polskiego Oświecenia, red. E. Wichrowska, Warszawa 2007, s. 167n.; H. Jurga, M. Wróblewska-Markiewicz, Tkanina, strój i jego akcesoria jako wyraz nastrojów patriotycznych związanych z Sejmem Czteroletnim i Konstytucją 3 maja, [w:] Konstytucja 3 Maja w tradycji i kulturze polskiej, red. A. Barszczewska-Krupa, Łódź 1991, s. 584593; A. Roćko, Kontusz i frak. O symbolice stroju w XVIII-wiecznej literaturze polskiej, Warszawa 2015, passim [tu najnowsza literatura]. 
sób symboliczny; zaszło to znacznie dalej, niż mógł przewidywać sam Męciński. Warto wskazać na jeden, ale za to bardzo spektakularny przykład. Stanisław August pisał z Warszawy 14 lipca 1792 roku do posła polskiego w Petersburgu Augustyna Debolego o kondycji armii „[...] sam generał Kościuszko już prawie boso chodząc aż przyjąć musiał w podarunku parę butów od Łubieńskiego posła sieradzkiego, który jeździł do obozu, chcąc się sam przekonać o prawdziwym stanie naszego wojska" ${ }^{34}$. Na potrzeby armii organizowano spektakularne zbiórki, również w Lublinie, zwłaszcza w czerwcu 1792 roku $^{35}$. Nauki Wojciecha Męcińskiego w las nie poszły.

\section{Bibliografia}

\section{Źródła}

Kazanie o dobrowolney ofierze na naglace potrzeby oyczyzny w dzień Oczyszczenia Nayswiętszey Maryi Panny w kosciele S. Ducha... miane..., Lublin 1789.

Kazanie o potrzebie woyska y iego podległości z ewangelij na niedziele III po Trzech Królach, o setniku żotnierzu, miane w kosciele lubelskim Świętego Ducha..., Lublin 1790.

Koźmian K., Pamiętniki, t. 1, oprac. M. Kaczmarek, F. Pecold, wstęp i komentarz J. Willaume, Wrocław-Warszawa-Kraków 1972.

Męciński J., Kazania niedzielne y świętalne przez x. Józefa Męcińskiego Prowincyi Mało-Polskiey reformata kaznodzieię zebrane w kościele Lubelskim u S. Ducha Powiedziane i do druku za Dozwoleniem Zwierzchności Podane, t. 1-2, Kraków 1791-1793.

Nayskuteczneyszy sposób poprawy powszechney gospodarstwa w nasz kray wprowadzenia uformowanie kraiowey kompanii ekonomiczney który projekt tu się podaie, t. 1, Warszawa 1783.

Rok nadziei i rok klęski 1791-1792. Z korespondencji Stanisława Augusta z postem polskim w Petersburgu Augustynem Deboli, wybór i oprac. J. Łojek, Warszawa 1964.

Sołtyk M., Mowa Jw. Jмсı Xiędza [...] Koadiutora Kantora Gnieźnieńskiego Prezydenta Trybunatu Koronnego [...] miana w Lublinie przy Limicie Trybunału, Roku 1786, Miesiąca Grudnia, dnia 2o, [Lublin].

Vautrin H., Obserwator w Polsce, [w:] Polska stanisławowska w oczach cudzoziemców, t. 1, wstęp i oprac. W. Zawadzki, tłum. J. I. Kraszewski, Warszawa 1963, s. 704-829.

${ }^{34}$ Rok nadziei i rok klęski 1791-1792. Z korespondencji Stanisława Augusta z posłem polskim w Petersburgu Augustynem Deboli, wybór i oprac. J. Łojek, Warszawa 1964, s. 166.

${ }_{35}$ J. Kermisz, Lublin i Lubelskie w ostatnich latach Rzeczypospolitej (1788-1794), t. 1, Lublin 1939, s. 125 n. 


\section{Opracowania}

Ajewski K., O ubiorze sejmowym 1776-1815, [w:] Arma virumque cano. Profesorowi Zdzisławowi Żygulskiemu w osiemdziesięciopięciolecie urodzin, Kraków 2006, s. 399-408.

Biedrońska-Słotowa B., Polski ubiór narodowy zwany kontuszowym, Kraków 2005.

Butterwick R., Polska rewolucja a Kościół katolicki, tłum. M. Ugniewski, Kraków 2012.

Dumanowski J., Francuski czy niemiecki. Francuska moda, rywalizacja społeczna i elitarna tożsamość w Polsce XVIII wieku, [w:] W stronę Francji... Z problemów literatury i kultury polskiego Oświecenia, red. E. Wichrowska, Warszawa 2007, s. 141-155.

Dziok-Strelnik I., Bibliografia starych druków lubelskich 1630-180o, Lublin 1997.

Gombin K., Trybunał Koronny. Ceremoniał i sztuka, Lublin 2013.

Jeziorowski T., Jeziorkowski A., Mundury wojewódzkie Rzeczypospolitej Obojga Narodów, Warszawa 1992.

Jougan A., Homilie polskie, Lwów 1902.

Jurga H., Wróblewska-Markiewicz M., Tkanina, strój i jego akcesoria jako wyraz nastrojów patriotycznych związanych z Sejmem Czteroletnim i Konstytucja 3 maja, [w:] Konstytucja 3 Maja w tradycji i kulturze polskiej, red. A. Barszczewska-Krupa, Łódź 1991, s. 584-593.

Kermisz J., Lublin i Lubelskie w ostatnich latach Rzeczypospolitej (1788-1794), t. 1, Lublin 1939.

Kornacki J., Problematyka zbytku w publicystyce „Monitora” (1765-1785), „Kwartalnik Historii Kultury Materialnej” (1985) nr 4, s. 417-425.

Lileyko J., Zamek Warszawski, rezydencja królewska i siedziba władz Rzeczypospolitej (1569-1763), Warszawa 1984.

Maksimowicz K., Konstytucja 3 maja w anonimowej poezji politycznej lat 1791-1792, [w:] „Rok Monarchii Konstytucyjnej”. Piśmiennictwo polskie z lat 1791-1792 wobec Konstytucji 3 maja, red. T. Kostkiewiczowa, Warszawa 1992, s. 77-111.

Mansel P., Dressed to rule. Royal and court costume from Louis XIV to Elizabeth II, New Haven-London 2005.

Prejs M., Egzotyzm w literaturze staropolskiej. Wybrane problemy, Warszawa 1999.

Roćko A., Kontusz i frak. O symbolice stroju w XVIII-wiecznej literaturze polskiej, Warszawa 2015.

Roćko A., Kontusz i frak jako symbole postaw osiemnastowiecznych Sarmatów, [w:] W stronę Francji... Z problemów literatury i kultury polskiego Oświecenia, red. E. Wichrowska, Warszawa 2007, s. 156-171.

Roćko A., Rola stroju francuskiego w literaturze polskiej drugiej połowy XVIII wieku, [w:] Europejski wiek osiemnasty. Uniwersalizm myśli, różnorodność dróg. Studia i materiaŁy, red. M. Dębowski, A. Grześkowiak-Krwawicz, M. Zwierzykowski, Kraków 2013, s. $163-173$.

Rosenblum R., Transformations in late eighteenth century art, Princeton 1967. 
Ślusarska M., Sejm Czteroletni w okolicznościowym kaznodziejstwie lat 1788-179o, [w:] Ku reformie państwa i odrodzeniu moralnemu człowieka, red. P. Żbikowski, Rzeszów 1992, s. 65-80.

Urbaniak A., Ubiory szlachty polskiej w czasach stanisławowskich w opinii współczesnych, „Kwartalnik Historii Kultury Materialnej” (1985) nr 3, s. 463-475.

Wiśniowski G. A., Męciński Wojciech, [w:] Polski słownik biograficzny, t. 20, Wrocław 1975 , s. $495-496$.

Zakrzewski A. J., Idee Oświecenia w kazaniach polskich. Studium literacko-socjologiczne, Częstochowa 1986.

\section{Abstrakt}

Ksiądz Józef Męciński (1748-1814) to postać mająca od dawna swe miejsce zarówno w opracowaniach dotyczących dziejów polskiej homiletyki, jak i idei społeczno-gospodarczych czasów stanisławowskich. W latach 1786-1793 Męciński przebywał w Lublinie. Poczynając od 1788 roku. wygłosił w kościele św. Ducha serię kazań kierowanych do szlachty, w których nawiązywał do aktualnych wydarzeń - obrad Sejmu Czteroletniego. Jego opinie o modzie wpisują się w ówczesną dyskusję o modzie, obyczaju i roli rzemiosła. Męciński w swoich kazaniach głosił popularne w czasach oświecenia idee merkantylistyczne, zbytek w ubieraniu się porównywał do trądu, postulował, aby szlachta nosiła ubrania szyte jedynie z materiałów wyprodukowanych w Polsce.

Podobne opinie już w latach 70. XviıI wieku przeczytać można było na łamach czasopisma „Monitor”, problemem tym zajmowały się też konstytucje sejmowe. Trudno się jednak dziwić, że Męciński w kazaniach zajął się ubiorem, który podczas Sejmu Wielkiego zyskał szczególny, polityczny wymiar. W kilku zdaniach omawianego lubelskiego kazania Józefa Męcińskiego mieści się właściwie esencja dyskusji z czasów stanisławowskich dotyczącej strojów i zbytku (brak jedynie wątku stroju narodowego), część jego poglądów zdaje się jednak oryginalna.

\section{Słowa kluczowe}

ksiądz Józef Męciński, okres stanisławowski, homiletyka, Lublin, Sejm Czteroletni 


\begin{abstract}
"Ścisk na podatki, a suknia tak długa, że się po ziemi wlecze”, or the political aspect of fashion in the sermons of rev. Joseph Męciński, delivered in Lublin at St. Spirit's Church during the Great Seym
\end{abstract}

Rev. Joseph Męciński (1748-1814) was a significant figure in both studies of the history of Polish homiletics and socio-economic issues of the Stanislavian period. Between 1786 and 1793 Męciński resided in Lublin. Starting from 1788 when he delivered a series of sermons addressed to the nobility at St. Spirit's Church, in which he referred to current events - the meeting of the Four Years' Seym. His opinions about fashion fit well into the contemporary discussion about the above, as well as customs and role of craft. In his sermons Męciński elaborated on mercantilist ideas, popular as they were during the Enlightenment. He would also compare dressing lavishly to leprosy, advocating the nobility to wear clothes produced from fabric made in Poland only.

It was possible to trace similar ideas already in 1770 s in the "Monitor" newspaper. These problems were being dealt with by Polish parliamentary constitutions as well. Yet it is hardly surprising that Męciński elaborated on the dressing code, which gained significant political dimension during the Great Seym. Short as it seems, Męciński’s Lublin sermon summarizes the essence of Stanislaus period's discussions about clothes and opulence (the national costume issue was not covered). Some of his views seems to be unchanged.

\title{
Keywords
}

rev. Józef Męciński, Stanislavian period, homiletics, Lublin, Four Years' Seym 